Original Contribution

\title{
METHODOLOGY FOR REPORTING OF THE ENERGY AND PROTEIN TRANSFORMATION IN THE ECO-TECHNICAL CHAIN "FEED-EGG MELANGE" BY LAYING HENS THROUGH INTRODUCING OF "CLARC OF ENERGY TRANSFORMATION/CLARC OF PROTEIN DISTRIBUTION”
}

\author{
D. Penkov ${ }^{*}$, S. Grigorova ${ }^{2}$ \\ ${ }^{1}$ Agricultural University, Plovdiv, Bulgaria \\ ${ }^{2}$ Department of Nutrition, Physiology, Ecology and Quality of Animal Production, Institute of \\ Animal Sciences - Kostinbrod, Bulgaria
}

\begin{abstract}
A methodology to account for transformation of metabolizable energy and crude protein in compound feed for laying hens to energy and protein in egg melange (albumen and egg yolk) has been developed. The introduction of Clarc of metabolizable energy transformation and Clarc of crude protein distribution could help to more exactly account of net utilization of nutrients in the eco-technical feed chain. "Clarc" is the ratio of the nutrients studied between primary (feed) and secondary level (animal products, edible by humans). For their establishing, original formulas have been used. They could be used in at least three important areas - ecological (bio-transformation); selectional (development of objective selection criteria and indices) and technological (as indicators to improve the feeding and housing technologies). In the scientific experiment the following values of energy and protein transformation in experiments with laying hens from Lohman Brown Klassik hybrid are observed: Clarc of metabolizable energy transformation (fodder-egg melange) - 0.2313 (23.13\%); Clark of crude protein distribution (fodder-egg melange) $-0.2096(20.96 \%)$.
\end{abstract}

Keywords: Crarc of energy transformation, Clarc of protein distribution, “fodder-egg mélange”, layers

\section{INTRODUCTION}

The need for the introduction of an evaluation system for the net utilization of nutrients and feed energy by the farm birds has been discussed for quite a long time. The individual nutrients (proteins, fats and carbohydrates) are used for energy deposition with different efficiency, despite the fact that the exchangeable energy is primarily used for reporting the nutritional energy in poultry feeds $(1,2)$. In this regard, Penkov and Genchev (3) suggested the introduction of an objective universal criterion for reporting the productive effect of the exchangeable energy and crude protein supplied by feed consumed, by developing the system "Clarc of (metabolizable) energy transformation" and "Clarc of (crude) protein distribution" - CET and CPD. The authors believe that

*Correspondence to: D. Penkov, Agricultural University, 12 D. Mendeleev Str., Plovdiv, Bulgaria, E-mail:dimopenkov@gmail.com complementing the research studies with those characteristics will give a more accurate picture of both the production capacity of a given feed and its introduction into poultry husbandry. Last but not least, they are also the basis of environmental monitoring of the feed - livestock production food chain. The term "Clarc of concentration/Clarc of biological accumulation/distribution" is used in ecology of heavy metals and represents the ratio between the contents of the element in the primary and secondary units in the ecological or eco-technical chain, when artificial, not typically natural, most often human activity, is involved $(4,5)$.

In poultry farming, Clarcs indicate how much of the energy and protein (amino acids) uptake has been transformed into human-edible poultry products (either as a whole number or as a percentage). The system was developed for the meat production direction (3). A methodology for determining their transfer 
from feed to edible egg parts (yolk, albumen and mélange) egg albumen and yolk (egg mélange) is proposed in egg production.

The aim of the study was to develop a methodology for introducing "Clarc of (metabolizable) energy transformation (CET)" and "Clarc of (crude) protein distribution (CPD)" on the basis of studies carried out with laying hens and to show with a real example how they are calculated.

\section{MATERIALS AND METHODS}

The experiment was conducted in 2017 at the Experimental Site of Poultry Farming at the Institute of Animal Sciences in Kostinbrod with a total of 60 laying hens of Lohman Brown Classic, starting their laying period at the age of 19 weeks. A two-phase feeding regime was used. The birds received $130 \mathrm{~g}$ of combined feed per hen daily. The composition and nutritional value of the feed are presented in Table 1. The experiment lasted 41 weeks (from 19 to 60 weeks of age). During the experiment, the following characteristics were monitored:

- Feed consumption - on a daily basis, using
PENKOV D., et al. the formula: Feed offered to the group Residual amount/Number of birds;

- Number of the eggs laid - daily, using the formula: Total eggs laid/Number of birds;

- Weight of the eggs laid, using scales with an accuracy of $0,1 \mathrm{~g}$ - daily;

- 10 eggs of each 100 produced eggs were selected, the weight of which was close to the mean weight, and their albumen, yolk and shell weight was measured;

- From each 200 broken eggs, the yolks and albumen were mixed and an average sample was taken for analyzing the major indicators according to the official methods of analysis of AOAC (6). For the calculating of the Clarcs of energy distribution (CED) and protein transformation (CPT), the formulas, proposed from Penkov and Genchev (3) were used: $\mathrm{CED}=\mathrm{MJ}$ gross energy $(\mathrm{GE})$ obtained from 1 layer (given by egg white/yolk) / MJ metabolizable energy (ME) consumed for the whole egg laying period [1]

$\mathrm{CPT}=\mathrm{kg}$ crude protein $(\mathrm{CP})$ obtained from 1 layer (given by egg white/yolk) / $\mathrm{kg} \mathrm{CP}$ consumed for the whole egg laying period [2]

Table 1. Composition and nutritional value of the combined fodders for the layers

\begin{tabular}{|c|c|c|}
\hline Components (\%) & $\begin{array}{c}\text { I phase } \\
\text { (19-28 weeks of age) }\end{array}$ & $\begin{array}{c}\text { II phase } \\
\text { (29-60 weeks of age) }\end{array}$ \\
\hline Maize & 5 & - \\
\hline Wheat & 57.14 & 65.04 \\
\hline Sunflower meal - 35\% CP & 11.00 & 12.00 \\
\hline Soybean meal $-46.4 \% \mathrm{CP}$ & 13.50 & 10.50 \\
\hline Sunflower oil & 3.00 & 2.00 \\
\hline Chalk $-39 \% \mathrm{Ca}$ & 8.50 & 4.30 \\
\hline Coarse chalk & - & 4.30 \\
\hline Monocalcium phosphate & 0.60 & 0.60 \\
\hline Paradigmox ${ }^{\circledR}$ & 0.01 & 0.01 \\
\hline BC $6015 \AA$ & 1.25 & 1.25 \\
\hline 6 phytase EC 3.1.3.26. (4a18) & $500 \mathrm{FYT} / \mathrm{kg}$ & $500 \mathrm{FYT} / \mathrm{kg}$ \\
\hline 1.4. $\beta$ xilanase & $150 \mathrm{FXU} / \mathrm{kg}$ & $150 \mathrm{FXU} / \mathrm{kg}$ \\
\hline \multicolumn{3}{|c|}{ Content in $1 \mathrm{~kg}$ fodder } \\
\hline Metabolizable energy - MJ & 11.45 & 11.34 \\
\hline Crude protein $\%$ & 17.64 & 16.72 \\
\hline Crude fats, $\%$ & 4.08 & 3.31 \\
\hline Crude fiber, $\%$ & 5.08 & 4.23 \\
\hline Lysine, $\%$ & 0.91 & 0.82 \\
\hline Methionine, $\%$ & 0.47 & 0.44 \\
\hline $\mathrm{Ca}, \%$ & 3.65 & 3.60 \\
\hline $\mathrm{P}$ (total), \% & 0.56 & 0.51 \\
\hline
\end{tabular}

\section{RESULTS AND DISCUSSION}

Table 2 presents the summarized results at the input of the eco-technical chain- metabolizable energy (ME) and crude protein (CP) consumed by a layer for the whole laying period. 
The calculations were made by the following formula:

Total consumed ME $(\mathrm{CP})=$ total consumed fodder for the 1st phase*energy/protein in the fodder + total consumed fodder for the 2 nd phase*energy/protein in the fodder $+\ldots$ (the same when there are other phases of feeding). The calculations were made on the base of the following formula:

Daily feed consumption was within the normal range for the hybrid. For example, on the official website of the Lohman Classic Brown
PENKOV D., et al. hybrid, the permissible consumption of compound feed is $125 \mathrm{~g}$ on average (7). At the beginning of egg production it is 120 , at the peak of egg production 125-130 $\mathrm{g}$ and in the second phase - 120-125 g. Our results corresponded to those reported by (8-10).

The amounts of exchangeable energy and protein uptake were also within the normal range, due to the fact that in both feeding phases the recommendations for their content in $1 \mathrm{~kg}$ of feed were followed $(7,11)$.

Table 2. Fodder, metabolizable energy (ME) and crude protein $(C P)$ from 1 layer for the whole experimental period (entrance of the system)

\begin{tabular}{lcc}
\hline Indexes & $\begin{array}{c}\text { I phase (19-28 } \\
\text { weeks of age) } \\
\text { LS } \pm \text { SEM }\end{array}$ & $\begin{array}{c}\text { II phase (29-60 } \\
\text { weeks of age) } \\
\text { LS } \pm \text { SEM }\end{array}$ \\
\hline $\begin{array}{l}\text { Daily fodder consumption from 1 layer, kg } \\
\text { Fodder consumption from 1 layer total for the phase, }\end{array}$ & $\begin{array}{c}0.120 \pm 0.014 \\
\text { kg }\end{array}$ & $0,127 \pm 0.019$ \\
ME consumption from 1 layer/per phase, MJ & $86.56 \pm 0.88$ & $28.45 \pm 4.26$ \\
$\begin{array}{l}\text { Total ME consumption from a layer for the whole } \\
\text { period (19-60 weeks of age) - MJ }\end{array}$ & \multicolumn{2}{c}{$409.18 \pm 40.09$} \\
$\begin{array}{l}\text { CP consumption from 1 layer/per phase, kg } \\
\begin{array}{l}\text { Total CP consumption from 1 layer for the whole } \\
\text { period (19-60 week of age), kg }\end{array}\end{array}$ \\
\hline
\end{tabular}

Table 3 shows the results of the egg weight obtained, including the edible egg components at the output of the eco-technical chain. The laying capacity of hens for the period $(242.18$ eggs per layer in average), corresponding to a laying intensity of $84.30 \%$, was also similar to that cited by a number of authors (12-16), as well as within the normal range for the hybrid (7). The same refers to the average egg weight, the reported average weight being 63-65 g.

Table 3. Produced egg mass from 1 layer 19-60 week of age (exit of the system)

\begin{tabular}{lll}
\hline Indexes & LS & SEM \\
\hline Eggs per hen housed for the laying period (average) & 242.18 & 3.15 \\
Eggs Mass per Hen Housed, g & 65.58 & 0.88 \\
Average mass of the egg yolk (from 1 egg), g & 16.84 & 0.22 \\
Average mass of the egg white (from 1 egg), g & 42.25 & 0.73 \\
Produced egg mass from 1 layer for the whole period, kg & 15.88 & 2.30 \\
Produced egg yolk mass from 1 layer for the whole period, kg & 4.08 & 0.69 \\
Produced egg white mass from 1 layer for the whole period, kg & 10.23 & 2.30 \\
\hline
\end{tabular}

For calculating the Clarcs of distribution/transformation, it is necessary to find the weight of the actually edible parts of the eggs produced - albumen, yolk and mélange (Table 3), as well as the gross energy and crude protein content in them (Table 4).

The gross energy and crude protein content in eggs are thought to be relatively constant, but in experiments with different genetic types of hens, carried out by $(17,18)$, significant differences were reported: in $1 \mathrm{~kg}$ dry matter, the metabolizable energy in yolk varied from 29.06 to $30.51 \mathrm{MJ}$, in albumen - from 19.77 to 20.92 MJ and the crude protein varied from 302.0 to $331.7 \mathrm{~g}$ in yolk and from 823.6 to $892.5 \mathrm{~g}$ in albumen. The chemical composition and energy content established in the present study were close to the average cited data. 
PENKOV D., et al.

Table 4. Chemical composition of the eggs, produced gross energy $(G E)$ and crude protein $(C P)$ from 1 layer and Clarc's of distribution/transformation

\begin{tabular}{|c|c|c|c|c|}
\hline \multirow{2}{*}{ Chemical and energy composition } & \multicolumn{2}{|c|}{ Egg white (native substance) } & \multicolumn{2}{|c|}{ Egg yolk (native substance) } \\
\hline & LS & SEM & LS & SEM \\
\hline Dry matter, \% & 11.66 & 0.02 & 49.90 & 0.04 \\
\hline $\mathrm{CP}, \%$ & 9.52 & 0.01 & 14.83 & 0.01 \\
\hline Crude fats, $\%$ & 0.31 & 0.01 & 30.06 & 0.26 \\
\hline Non protein extract, $\%$ & 0.91 & 0.01 & 3.32 & 0.02 \\
\hline Ash, \% & 0.75 & 0.01 & 1.67 & 0.01 \\
\hline $\mathrm{GE}, \mathrm{MJ} / \mathrm{kg}$ & 3.206 & 0.03 & 15.155 & 0.09 \\
\hline $\begin{array}{l}\text { Total produced GE from } 1 \text { layer (19- } \\
60 \text { weeks of age) - MJ }\end{array}$ & 32.80 & 0.07 & 61.83 & 0.08 \\
\hline $\begin{array}{l}\text { Total produced CP from } 1 \text { layer (19- } \\
60 \text { week of age) - kg }\end{array}$ & 0.672 & 0.01 & 0.605 & 0.01 \\
\hline Clarc of energy distribution (CED) & \multicolumn{2}{|c|}{$0.0802(8.02 \%)$} & \multicolumn{2}{|c|}{$0.1511(15.11 \%)$} \\
\hline $\begin{array}{l}\text { fodder - egg component } \\
\text { Clarc of energy distribution } \\
\text { (CED) fodder - egg mélange }\end{array}$ & \multicolumn{4}{|c|}{$0.2313(23.13 \%)$} \\
\hline $\begin{array}{l}\text { Clarc of protein transformation } \\
\text { (CPT) fodder - egg component } \\
\text { Clarc of protein transformation } \\
\text { (CPT) fodder - egg mélange }\end{array}$ & \multicolumn{2}{|c|}{$0.1103(11.03 \%)$} & $0.2096(20.96 \%)$ & $\%)$ \\
\hline
\end{tabular}

The most significant effect on Clarcs of distribution/transformation was actually exerted by the gross energy (GE) and crude protein $(\mathrm{CP})$ produced by hens (Table 3).

Multiplying the obtained egg albumen and egg yolk weights by the gross energy/crude protein content in one kilogram of them, produces the actual amount of transformed substances in the secondary unit of the eco-technical chain - the edible animal product. In contrast to the feed conversion ratio (FCR) cited from (19) and European Poultry Efficiency Factor (EPEF) cited from (20), in that case the actual transformation is reported (eliminating the differences in the water content in the primary and secondary units) - Table 4.

In the present study, a relatively high energy transformation (over 23\%) and protein transformation from feed to egg mélange $(21 \%)$ was obtained.

\section{CONCLUSIONS}

The following results from the experiment have been observed:

For the Clarc of energy distribution - CED (from feed to egg mélange):

-to egg albumen - $0.802(8.02 \%)$

-to egg yolk $-0.1511(15.11 \%)$

-total (to the mélange) - $0.2313(23.13 \%)$

For the Clarc of crude protein transformation -

CPT (from feed to egg mélange)

-to egg albumen $-0.1103(11.03 \%)$

-to egg yolk - $0.0993(9.93 \%)$

-total (to the mélange) - $0.2096(20.96 \%)$
The introduction of "Clarcs of energy distribution/protein transformation" system contributes to more accurate establrshing the net recovery of the energy and protein from animal feed in the real consumed human products. In this aspect, they can be used in at least three important directions: ecological (bio - transformation), selectional (development of objective selection criteria and indices) and technological (as indicators to improve the feeding and housing technologies).

\section{REFERENCES}

1. Cooke, B., The impact of declaration of the metabolisable energy (ME) value of poultry feeds. In: W. Haresign and D.J.A. Cole (Eds.), Recent advances in animal nutrition, London: UK, pp 19-26, 1987.

2. Pirgozliev, V. and Rose, S.P., Net energy systems for poultry feeds: a quantitative review. World's Poultry Science Journal, 55, 1): 23-36, 1999 https://doi.org/10.1079/WPS19990003 .

3. Penkov, D. and Genchev A., Methods for introduction of objective criteria for bioconversion of energy and nutrients along the feed - animal products chain in meettype poultry farming. $J$. of Central European Agriculture, 19 2): 270-277, 2018 DOI: /10.5513/JCEA01/19.2.2152 .

4. Baykov, B., An objective method for assessment of the movement of the chemical elements in anthropogenic ecosystem, (domestic animal farms). 
Toxicology environmental chemistry, 42: 227-233, 1994.

5. Dobrovolskiy, V., Introduction to biochemistry, Moscow, Visshaya shkola, 1998 (in Russian).

6. AOAC international, Official methods of analysis of AOAC (18 edition, rev. 2), Association of Official Analytical Chemists, Gaithersburg, MD, USA, 2007.

7. Lohmann Tierzucht: http://www.ltz.de/en/layers/alternativehousing/lohmann-brown-classic.php (date last accessed: 2019).

8. Farooq, M, Mian, M. A., Durani, F. R. and Syed, M.., Feed Consumption and efficiency of feed utilization by egg type layers for egg production. Livestock Research for Rural Development, 14(1): 2002.

9. Petek, M., Production traits and economic efficiencies of different genotypes of layers reared by enterprises in Bursa province and its near vicinity. Veterinar Fakultesi Dergisi Uludag Universitesi, 18 (1-2): 6577, 1999.

10.Lukanov, H., Petrov, P., Genchev, A., Halil, E.and Ismail, N., Productove performance of Easter egger crosses of Araucana and Schijndelaar roosters with White Leghorn hens. Trakia Journal of Sciences, 1: 72-79, 2016.

11.Marinov, B., Feeding of layers, Sofia, 2004 (In Bulgarian).

12.Hy-line, Brown/white performance standards manual (2-nd Ed.) 2011.

13.ISA Brown, 2010, https://www.isapoultry.com/en/product/isa-brown/.
PENKOV D., et al.

14. Oyedeji, J. O., Odogwu, T. O. and Ajay, H., Laying performance of Lohman Brown hens fed Gashew nut waste meal, with or without methionine supplementation as a replacement for soybean meal. Nigerian Journal of Agriculture, Food and Environment, 11(3): 156-161, 2015.

15.Pottgueter, R., Egg weight - Nutrition and feeding management in rearing and start production period. Lomann tierzucht GMBH, Cuxhaven, Madrid. XII, 2010.

16.Sigh, R., Cheng, K. M. and Silversides, G., Production performance and egg quality of four strains of laying hens kept in conventional cages and floor pens. Poultry Science, $\quad 88(2)$ : 256-264, 2009. https://doi.org/10.3382/PS.2008-00237.

17.Antova, G., Gerzilov, V., Petkova, Zh., Boncheva, V., Bozhichkova, I., Penkov, D. and Petrov, P., Comparative analysis of nutrient content and energy of eggs from different chicken genotypes. J. of Science of Food and Agriculture 99: 5890-5898, 2019 DOI 10.1002/jsfa.9863 .

18. Gerzilov, V., V. Boncheva and P. Petrov, Egg production from dual purpose hen genotypes reared in a free range system, Bulg. J. Agric. Sci., 24 (1): 119-125, 2018 .

19.Kabakchiev, M., Alexieva, D., Genchev, A., Nikilova, M. and Gerzilov V., Poultry breeding, Academic Press, Agricultural University, Plovdiv, 2014. (In Bulgarian).

20.Lalev, M., Mincheva, N., Hristakieva, P. and Oblakova, M., Effect of dietary inclusion of rumanol ML vegetable fat on fattening hybrid turkey broiler. Trakia Journal of Sciences, 4: 320-326, 2018. 